\title{
De nuevo la vida. El poder de la Noviolencia y las transformaciones culturales
}

\author{
Again the life. \\ The power of non violence and the cultural transformations \\ Carlos Eduardo Martínez Hincapié (2012). Corporación Universitaria Minuto de Dios: Bogotá.
}

工

a Dirección de Investigaciones y el Centro de Pensamiento Humano y Social de la Sede Principal de Uniminuto el libro De nuevo la Vida. El poder de la noviolencia y las transformaciones culturales del profesor Carlos Eduardo Martínez Hincapié.

Martínez Hincapié es miembro del Centro de Pensamiento Humano y Social, así como del grupo de Investigación Ciudadanía, Paz y Desarrollo; está vinculado a Uniminuto desde hace 15 años, cofundador de Benposta-Nación de muchachos. Impulsor del Movimiento Ciudadano por la Noviolencia con muchas otras personas y organizaciones sociales, y partícipe del proceso que significó el Mandato Ciudadano por la Paz, la Vida y la Libertad en 1997. Lo anterior para señalar la estrecha relación de su experiencia vital, de su especial conexión con la vida, sus preocupaciones urgentes por la paz en un país como Colombia, así como su conciencia del poder que cada persona puede ejercer para transformar la realidad y hacer que el mundo sea mejor con este libro, el cual nos ofrece una mirada a contracorriente $[\ldots]$ ver e interpretar la realidad con nuevos ojos, con otras razones, con otros sabores. Un libro lleno de atrevimientos, fruto de recoger los caminos recorridos en la vida y resultado de su tesis de investigación doctoral en Paz, Conflictos y Democracia de la Universidad de Granada-España.

De nuevo la Vida forma parte del ámbito de la investigación para la paz y aporta al campo específico de la noviolencia, lo cual es una primera novedad de este trabajo. Sí, la noviolencia como una propuesta de transformación cultural y una afirmación contundente: "Está sucediendo [...] otros mundos son posibles" (2012, p. 24). En este sentido, el objetivo del libro es el de encontrar y visibilizar las alternativas culturales que se han venido construyendo desde los movimientos sociales, a partir de reconocer y problematizar los imaginarios atávicos que han sostenido

1 Estudiante del Doctorado en Educación, Universidad Central de Nicaragua. Abogada de la Universidad Católica de Colombia. Estudios de maestría en Estudios Latinoamericanos. ILADES: Santiago de Chile. Especialista en Derecho Comercial y Financiero de la Universidad Católica de Colombia. Correo electrónico: luisaf.gonzalezm@gmail.com 
la cultura hegemónica, como producto de una construcción social e histórica para proteger y dar continuidad a la vida, y que sin embargo hoy están en contravía de la misma.

La hipótesis principal se define en estos términos:

La cultura como instrumento por excelencia a través del cual los seres humanos construimos la interpretación de la realidad que nos circunda y con la cual establecemos mecanismos colectivos de adaptación, entendiendo este proceso como lo que es viable para la continuidad de la vida y su fuerza inmanente que le da sentidos y contenidos al quehacer humano (2012, p. 27).

Entonces, la cultura es el mecanismo que garantiza la vida y su continuidad, el cual se legitima de esta manera y, no obstante, puede en un momento dado ponerla en peligro y amenazarla casi hasta su extinción, como de hecho se evidencia en el acontecer del último siglo y principios del XXI: si la cultura es una construcción social e histórica, es vigente sólo en la medida en que mantiene su capacidad para hacer posible la vida y se deslegitima socialmente cuando ya no es así.

El profesor Martínez introduce el concepto de imaginarios atávicos como aquellos elementos, comprensiones, aprendizajes colectivos, que se transmiten o heredan de forma inconsciente y que representan la base de aquellas significaciones más profundas de la vida social; los que definen las lógicas de las relaciones entre los seres humanos y con la naturaleza, los que dan la certeza necesaria de la supervivencia, los cuales a su vez se pueden volver verdades incuestionables, siendo entonces la columna vertebral de la cultura al trascender la racionalidad social. Estos imaginarios atávicos son entonces los que conforman el esqueleto que define el cuenco cultural: "una especie de contenedor en el que se vierte la realidad, determinando sus comprensiones, sus alcances y limitaciones, las interpretaciones que se hacen de la misma y sus niveles de significación" (2012, p. 46). El autor ubica la consolidación social de los imaginarios atávicos que definen la cultura, hasta ahora hegemónica, en los procesos de sedentarización de los pueblos y comunidades humanas y de ello da cuenta intentando caminar por el terreno de las hipótesis al tratar de mirar cómo este tránsito del nomadismo al sedentarismo significó la revolución cultural más profunda de nuestra historia (Corbí, 1996, p. 28).

Con base en las hipótesis anteriores se da sustento a la primera parte del libro, haciendo énfasis en la conexión directa de la cultura con la vida, en un proceso permanente de conservación y cambio. La paradoja de la conservación y el cambio, puesto que la cultura es al mismo tiempo un sistema cerrado y abierto que permite conservar las construcciones sociales que han demostrado su capacidad para posibilitar la vida y cambiar aquellas que la amenazan y que en consecuencia pierden legitimidad social. Por lo tanto, la cultura entra en una profunda crisis de legitimidad, generándose con ello un proceso de cambio y transformación de los imaginarios que la sustentaban. Así mismo, se hace un recorrido por el cuestionamiento profundo que están teniendo las bases de la cultura humana hegemónica: crisis de la obediencia, del unanimismo, de los límites y las fronteras, de la ética del bien y del mal, del chivo expiatorio, del poder centralizado y jerarquizado, de la justicia retributiva, del miedo como mecanismo de regulación social, de las diferentes legitimaciones de las violencias, de la verdad absoluta, entre otras. Su conclusión es que una era de la humanidad está llegando a su fin; y con ella sus paradigmas civilizatorios, expresados en una conciencia colectiva cada vez más amplia, de estar llegando a los límites de la supervivencia, lo cual está demandando nuevos referentes cultuales, que habría que construir.

En la segunda parte el libro se plantea un nuevo recorrido: primero por los cuestionamientos a la cultura hegemónica a través del tiempo, transitando por algunos aspectos del mensaje de Jesús, de H.D. Thoreau y de León Tostói, a quienes el profesor Martínez nombra como precursores, porque nos han insinuado e insinúan en el presente, caminos de ruptura y acumulados significa- 
tivos en esta formación de la conciencia colectiva que pueda configurar un nuevo cuenco cultural; también porque sus pensamientos y propuestas influyeron de forma determinante en Mohandas Gandhi (el Mahatma), el hombre que, partiendo de estas opciones éticas, elaboró toda una propuesta de transformación política, económica y social, construyendo un continuo entre lo personal y lo social: la propuesta de la noviolencia, la cual no es sólo una táctica y una estrategia con capacidad de combinar muchas formas de protesta; tampoco es sólo un proceso ascendente de acumulación de fuerzas para tomar el poder, sino que se enuncia como la activación de las potencias humanas, las interiores y las que producen las relaciones y los afectos y cambian nuestros modos de existir, lo cual implica claramente la posibilidad de reconectarnos con los significados profundos de ese existir, de la vida en todas sus múltiples relaciones.

Igualmente, la reflexión propone en esta segunda parte del libro mostrar los nuevos referentes culturales que se insinúan y evidencian a través del actuar y el pensar de varios de los movimientos sociales que hoy están siendo protagonistas y sujetos de nuevas perspectivas, que se expresan en: formas de organización, relaciones más horizontales y colectivas, revoluciones que están cuestionando de fondo el poder que se enriquece, domina y mata a costa de la miseria colectiva y por lo tanto planteando otros poderes, el propio, el de pequeños grupos, en la periferia casi siempre. Todas estas evidencias que cuestionan los imaginarios atávicos con su sentido esencial de proteger y garantizar la vida, todas esas expresiones que proponen otras relaciones y visiones de otros mundos posibles, es lo que el autor nombra como una cultura que está emergiendo, la cultura de la noviolencia.

En este sentido, considera que la noviolencia es una propuesta de transformación cultural que bebe de las tradiciones más profundas de la humanidad: Jesús de Nazareth, Henry David
Thoreau y León Tolstói y se evidencia en los diversos movimientos sociales más importantes de los últimos cien años con sus aportes a esta cultura emergente de la noviolencia, deconstruyendo los imaginarios atávicos de la cultura hegemónica en una lógica creativa, señalando los puntos de fuga que van abriendo camino en la redefinición de las relaciones entre los seres humanos y de éstos con la naturaleza.

El autor nos señala los aportes de Gandhi y de la lucha por los Derechos Civiles en EE.UU, nos ubica en la década de los sesenta, como un momento que planteó profundas rupturas y alternativas a la cultura hegemónica, acercándose al movimiento hippie, a las primaveras de mayo del 68, a los nuevos feminismos y a los ecologismos, haciendo una lectura de los principales elementos de esta cultura emergente desde los nuevos movimientos sociales, los pacifismos, la caída del Muro de Berlín y del Apartheid en Sudáfrica, las primaveras árabes de 2011 y el movimiento de los Indignados en España.

El profesor Martínez enuncia su atrevimiento al llamar a esta cultura emergente la cultura de la noviolencia, porque cuestiona de forma radical la columna vertebral de la cultura hegemónica, evidenciando la crisis de la misma. También porque en los movimientos sociales que se nombraron en este libro, hay un caminar en proceso, un acontecer permanente de aprendizajes y transformaciones en una profunda conexión con la vida y, por lo tanto, un camino que está construyendo una ética de la misma, que los une sin que desaparezcan sus ricas y diversas particularidades. Y porque Gandhi, Mandela, las mujeres, los ecologistas, los pacifistas, Marthin Luther King, los grupos aborígenes y muchos más, las personas y cada uno(a) de nosotros somos hijos de una época, de una búsqueda colectiva, que necesita encontrar respuestas que hagan posible la vida. Necesitamos crear nuevos mundos, vivir las utopías de una vida plena, de un mundo fraterno y amoroso. 